\title{
Knowledge and attitude towards organ donation among people seeking health care in Kozhikode, Kerala, India
}

\author{
Paul B. ${ }^{1}$, Zameel A. ${ }^{2}$, Aisabi K.A. ${ }^{3}$, Kumar D. ${ }^{4}$, Sujesh P.K. ${ }^{5}$ \\ ${ }^{1}$ Dr. Benzy Paul, Associate Professor, Department of Pathology, ${ }^{2}$ Dr. Ali Zameel, Assistant Professor, Department of \\ Community Medicine, ${ }^{3}$ Dr. K. A. Aisabi, Professor \& Head, Department of Pathology, ${ }^{4}$ Durgesh Kumar, Statistician, \\ Department Of Community Medicine, ${ }^{5}$ Sujesh P.K., MSW, Department of Community Medicine; all authors are \\ affiliated with KMCT Medical College, Manassery, Kozhikode, Kerala, India.
}

Corresponding Author: Dr. Benzy Paul, Associate Professor, Department of Pathology, KMCT Medical College, Manassery, Kozhikode, Kerala, India. E-mail: drbenzypaul@gmail.com

\begin{abstract}
Introduction: Organ transplantation has been found to be the only possible treatment in most of the chronic illnesses. It would be possible to save thousands of lives by organ donation. It has been found that the issue of organ donation involves a lot of medical, legal, ethical, organizational and social factors. Although the shortage of organs has been found to be a global problem, the situation in Asia is much worse. The main reasons behind the low percentage of organ donation in India are lack of awareness, improper infrastructure facilities, myths and misconceptions regarding organ donation. Objective: To assess the knowledge and attitude of the people seeking health care, regarding organ donation in rural Kerala. Materials and Methods: A questionnaire was distributed amongst all willing patients and their relatives attending Medical College Hospital, Urban Health training centre and Rural Health training centre, after obtaining informed consent. A sample size of 360 subjects fulfilling inclusion and exclusion criteria was selected by simple random sampling. Results: The mean age of the study population was 53.6 \pm 11.8 with slight female preponderance. Majority of the participants had knowledge about donation of eye (97\%) and kidney (91\%).81\% of participants had obtained knowledge regarding organ donation from television and social media. $64.2 \%$ had good attitude and thought that organ donation should be promoted. Conclusion: Although most of the participants had knowledge about organ donation, willingness to donate was found to be limited. Healthcare professionals need to take an active role in clarifying any myths and doubts of people regarding organ donation, which cannot be accomplished through electronic media alone.
\end{abstract}

Keywords: Organ donation, knowledge, willingness, Brain death.

\section{Introduction}

Organ transplantation is the only available treatment in many chronic illnesses. Worldwide, organ transplantation saves thousands of lives [1]. The issue of organ donation is complex and multi-factorial, involving medical, legal, ethical, organizational, and social factors [2]. Countries around the world have reported that people's attitude towards organ donation is influenced by factors such as knowledge, education, and religion [3].

Organ shortages are a global problem, but Asia lags behind much of the rest of the world. There is a huge shortage of organs in India, and patients die while on the waiting list as they do not get an organ on time [4].

Manuscript received: $8^{\text {th }}$ September 2019

Reviewed: $20^{\text {th }}$ September 2019

Author Corrected: $30^{\text {th }}$ September 2019

Accepted for Publication: $7^{\text {th }}$ October 2019
Hence human organ donation was legalized in India in 1994 through 'The transplantation of Human Organs Act, 1994 [5]. According to MOHAN foundation as cited by Annadurai et al [4], even after 25 years of the act, every year, close to six lakh people die due to organ failure. Conversely, with 70 per cent of India's 1.4 lakh accident victims diagnosed as brain dead annually, the country has 80,000 potential organ donors. Yet, organs from only about 120 are retrieved, making the percentage of cadaver donations a dismal 0.08 per million of the population. Thus, current organ donation from cadavers in India is very less compared to Spain which tops the list with 35 per million.

Lack of awareness and improper infrastructure facilities along with myths and misconceptions associated with organ donation are the main reasons behind the low 


\section{Original Research Article}

percentage of organ donation [4]. To achieve cadaver organ donation, it is necessary to act at two levels: the health care workers and the general public [6]. The health care workers if trained can play a tremendous role in imparting knowledge and motivating patients and their relatives towards organ donation [7].

The general population needs to be educated about transplantation and the need to accept the commitment to donate organs as a new approach in solving the organ shortage.

It is therefore essential to assess the knowledge, awareness and attitude towards organ donation among patients attending health services for treatment before giving them health education.

Kerala is a state known for its high educational and health care standards. This study attempts to find out whether the knowledge and attitude towards organ donation is any different among rural population of Kerala.

\section{Materials and Methods}

Place, type and duration of study: A hospital based cross-sectional study was done, over a period of 6 months at Medical College hospital, Urban health training centre and Rural health training centre of KMCT Medical College where several people visit daily to seek treatment.

Sampling method and data collection: A sample size of 354 was calculated using a prevalence of $53 \%$ for good knowledge of organ donation from the previous study in South Kerala. A total of 360 subjects fulfilling inclusion and exclusion criteria were selected by simple random sampling. The activity was carried out in two parts. The first part consisted of studying the knowledge and awareness levels of the people, while the second part consisted of discussing body and organ donation with the people and clarifying their doubts.

The data was collected through direct interview of participants using a pre-designed close ended questionnaire.

The first section of the questionnaire gathered the sociodemographic details from the participants, which included age, gender, education, occupation, socioeconomic status (SES) and religion.

The second section of the questionnaire had categories for assessing knowledge, individual perceptions, willingness and barriers.

\section{Inclusion criteria}

All patients above 30 years of age formed our reference population. Participants who gave informed consent were included in the study.

\section{Exclusion criteria}

Critically ill patients and those who refused to give consent were excluded from the study.

\section{Statistical analysis}

Data entry was made in excel software in codes and analysis was done by SPSS software. Descriptive statistical analysis, which included frequency, mean, standard deviation and percentages, was used to characterize the data.

\section{Results}

Out of the 360 subjects interviewed 172(47.8\%) were men and 188(52.2\%) were women showing slight female preponderance. The mean age of the study population was $53.6 \pm 11.8$ years. Majority of the study population (57.8\%) was working, only $11.6 \%$ were housewives. About $51.1 \%$ people were Hindus and $45.8 \%$ of people were Muslims, and remainder Christians. The Kuppuswamy scale classified $5.3 \%$ of the population as lower SES.

Almost $99 \%$ of the participants had heard about organ donation. Each knowledge and attitude question was given a weighted score and total score for each domain was 20 . Scores below 7 were considered as poor, 8 to 14 as moderate and above 14 as good.

On this scale $58 \%$ participants had good knowledge about organ donation but $19 \%$ had poor knowledge.

Television and social media were the main source of information for participants $(81 \%)$. Other sources reported were newspapers, friends and relatives and hospitals. Majority of the participants $(97 \%$ \& $91 \%$ respectively) said that eyes \& kidneys can be donated, but only $38 \%$ and $26 \%$ of the participants respectively were aware that heart and liver can be donated. $13 \%$ thought that eyes can be donated while alive also.

Pathology Update: Tropical Journal of Pathology \& Microbiology Available online at: www.medresearch.in 778 | P a g e 
Table No. 1: Socio demographic characters of study population.

Original Research Article

\begin{tabular}{|l|c|c|}
\hline Characteristics & No. & \% \\
\hline Gender & 172 & 47.8 \\
\hline Male & 188 & 52.2 \\
\hline Female & & \\
\hline Age & 57 & 15.8 \\
\hline $30-40$ & 82 & 22.8 \\
\hline $40-50$ & 104 & 28.9 \\
\hline $50-60$ & 117 & 32.5 \\
\hline$>60$ & & \\
\hline Occupation & 208 & 57.8 \\
\hline Working & 19 & 5.3 \\
\hline Unemployed & 42 & 11.6 \\
\hline Housewife & 91 & 25.3 \\
\hline Retired & & \\
\hline Religion & 184 & 51.1 \\
\hline Hindu & 165 & 45.8 \\
\hline Muslim & 11 & 3.1 \\
\hline Christian & & \\
\hline Socioeconomic status & 32 & 8.9 \\
\hline I & 91 & 25.3 \\
\hline II & 143 & 39.7 \\
\hline III & 75 & 20.8 \\
\hline IV & 19 & 5.3 \\
\hline V & & \\
\hline
\end{tabular}

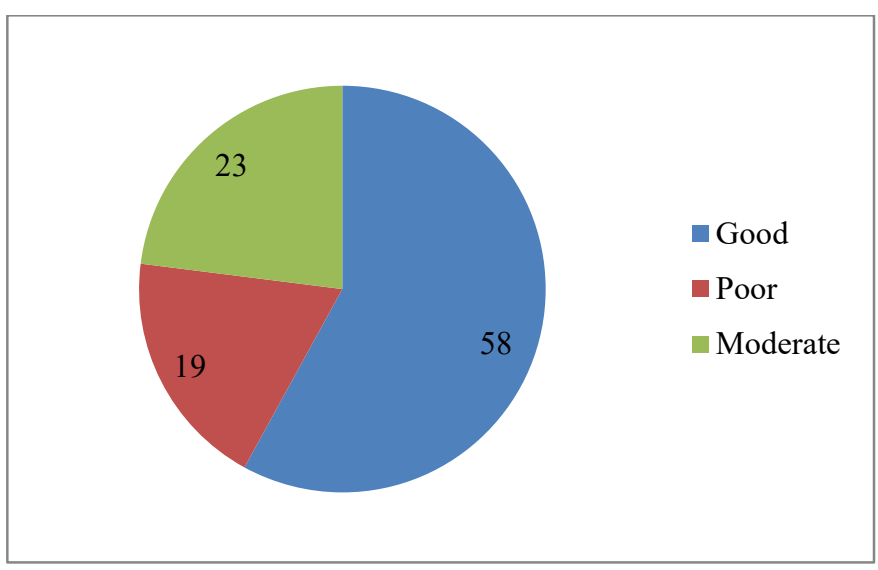

Figure 1: Knowledge about organ donation.

Table-2: Knowledge about organs that can be donated.

\begin{tabular}{|c|c|}
\hline Variable & Frequency \\
\hline Blood & $360(100 \%)$ \\
\hline Eyes & $349(96.9 \%)$ \\
\hline Kidney & $327(90.8 \%)$ \\
\hline Heart & $137(38 \%)$ \\
\hline Liver & $94(26.1 \%)$ \\
\hline
\end{tabular}


Original Research Article

Table-3: Attitude towards organ donation.

\begin{tabular}{|l|c|c|c|}
\hline Question & Yes & No & Don't Know \\
\hline Do you support organ donation? & $231(64.2 \%)$ & $61(16.9 \%)$ & $68(18.9 \%)$ \\
\hline Do you agree to donate organs when you die? & $172(47.8 \%)$ & $83(23 \%)$ & $105(29.2 \%)$ \\
\hline Do you agree to donate your family member's organs? & $147(40.8 \%)$ & $80(22.2 \%)$ & $133(37 \%)$ \\
\hline Does your family agree with organ donation? & $95(26.4 \%)$ & $79(21.9 \%)$ & $186(51.7 \%)$ \\
\hline $\begin{array}{l}\text { Do you have belief that your body should be kept intact after } \\
\text { death? }\end{array}$ & $71(19.7 \%)$ & $253(70.3 \%)$ & $36(10 \%)$ \\
\hline
\end{tabular}

Most of the respondents $64.2 \%$ had good attitude and thought that organ donation should be promoted. $44 \%$ participants thought that live organ donation could result in serious health problems and $32 \%$ of them thought that it can lead to cancer. It was the main barrier against organ donation. Other barriers included unknown fear 23\%, religious perceptions $14.5 \%$. Less than half, $47.8 \%$ showed willingness to donate organs. $19.7 \%$ subjects believed that body should be kept intact after death. Regarding knowledge of brain death, 33.7\% felt that heart will continue to beat due to ventilator support in brain dead individual. $11.6 \%$ only knew that brain dead person is legally dead while $49 \%$ stated that they had no idea about brain death.

\section{Discussion}

Organ donation and transplantation is the most important treatment modality of many end organ diseases. Many patients die while waiting for a transplant. Most important reason behind this is lack of awareness and knowledge among the entire population and many myths and beliefs accepted by people with respect to organ donation [8]. The gap between demand and supply can be reduced by creating awareness amongst general public and improving their knowledge.

In this study, it was interesting to see that almost $99 \%$ of the participants were aware about organ donation, which was similar to the findings in the study by Srinivas Rao G et. al [9]. This can be attributed to high literacy rate in the state of Kerala. Similar findings have been reported by the studies done in South Kerala [10] and Mangalore [11]. In the present study, the knowledge about organ donation was found to be good $(58 \%)$, moderate $(23 \%)$ and poor $(19 \%)$ among the participants.

In the study by Tamuli RP et al [12] done in Guwahati, $79.16 \%$ subjects were completely aware about organ donation, $16.67 \%$ were partially aware and $4.17 \%$ subjects were totally unaware about organ donation. But in the study done by Bhagya LM. et. al [13] in Tirupati, knowledge about organ donation was adequate in $7.5 \%$, moderate in $40 \%$ and inadequate in $52.5 \%$ of the participants. Kumar VMB et al [14] noted that, with regard to the knowledge assessment of organ donation, $43 \%$ had moderate level, 57\% had low level and none of them had high level of knowledge. Deepthi et al [15] found that $97.6 \%$ of subjects were aware about organ donation, $87 \%$ could tell the definition, and $56.9 \%$ showed complete knowledge about every aspect of organ donation. Sucharitha ST et al [16] in their study done in the state of Tamil Nadu which is considered to be the forerunner of organ donation in India, observed that $77 \%$ of the participants strongly approve organ donation. $6.6 \%$ of the participants of their study claimed to have had a history of organ donation in the family.

$81 \%$ of the respondents heard about organ donation from electronic media, whereas only $11 \%$ heard from health care workers. A study done in California [17] revealed that speaking to a physician about organ donation positively influenced the likelihood to donate an organ. So, this aspect needs to be addressed in Kerala. More than $90 \%$ of the study population knew that eyes and kidneys can be donated. Similar findings were reported in the study done in South Kerala [10], but in the study done in Pune [18] knowledge about kidney donation was found to be very less compared to the present study. $66.2 \%$ of study population of Saleem $\mathrm{T}$ et al [19] and $95.4 \%$ of participants of Soubhanneyaz A et al [20] were aware about kidney donation programs.

Tamuli RP et al [12] found that awareness about donation of eye $(82.5 \%)$, kidney $(77.5 \%)$, liver $(35.83 \%)$ and heart (35.83\%), whereas only $11.67 \%$ believed that most of the organs can be donated. In the present study, only $21.3 \%$ knew that kidney, eyes, blood, liver and heart all can be donated. This finding was slightly more than $16.1 \%$ reported in Chennai [4]. But Saleem Tet al [19] noted that $26.2 \%$ of participants of their study knew about multiple organ transplantation. 


\section{Original Research Article}

Most of the respondents $64.2 \%$ in the present study had good attitude and thought that organ donation should be promoted but only $47.8 \%$ showed willingness to donate organs. This finding is almost similar to the studies done in South Kerala [10] and Pune [18]; but much less than that reported in Chennai [4] and Mangalore [11]. More proportion of subjects in the present study were not selective in their desire to donate organs which was found to be similar to findings in the study conducted by Ramadurga UY and Gupta A [21].

Schauenburg $\mathrm{H}$ and Hildebrandt $\mathrm{A}$ found that only $17.71 \%$ of participants were seriously thinking and $54.5 \%$ were somewhat thinking to donate organs [22]. In the study conducted in Nigeria [23] only $30 \%$ of the participants expressed their willingness to donate their organs. Sahu et al [24] found that only $44.1 \%$ of participants were willing to donate their body after death, for organ donation. $57.9 \%$ of participants from the study done in Egypt [25] were willing to donate their organs. About $62.3 \%$ of participants of Saleem T et al [19] were keen to donate their organs. $72.7 \%$ of the subjects were willing to donate organs in the study done by Bathija GV et al [26]. Soubhanneyaz A et al [20] found that $73.5 \%$ of participants were interested in becoming an organ donor. $87 \%$ of participants from Brazil [27] showed the willingness to donate organs, but almost $96 \%$ of participants from Ohio [28] were keen to donate organs.

The main reasons in the subjects found to be not willing for organ donation were the lack of confidence in health care system and fear of commercialization [25]. In the present study, religious belief played a minor role for negative attitude for organ donation. This was similar to the findings in the studies done by Bapat $\mathrm{U}$ et al [29] and Dutra MMD et al [30]. But religious beliefs had no influence on the student's attitudes to organ donation in the study done by Burra $\mathrm{P}$ et al [31]. Although recently it has been seen that many efforts are being made by different NGOs for creating awareness towards organ donation [32,33] the success of such programs depends upon the active participation of all the educated people in the society.

\section{Conclusion}

This study found out that even though people know about organ donation, willingness for organ donation is less. In countries like India, there is a significant demand for organ donation. In spite of huge population, organ donation is very limited. It can be concluded that there is need to educate people about organ donation and registration for organ donation. This cannot be accomplished through electronic media alone, but health care professionals must intervene to clear all misbeliefs and doubts of people about organ donation and regarding its importance.

\section{What the study adds to the existing knowledge?}

The present study provides the current status of organ donation in Kozhikode, Kerala, India. From the study, it can be inferred that health care workers need to play a more active role in clearing all the myths and misbeliefs of people regarding organ donation, rather than depending on electronic media alone. The government needs to make the procedure of organ donation donor friendly by reducing the paperwork involved. NGOs also need to play an active role along with the health care workers to raise awareness about organ donation.

\section{Author's contribution}

Dr. Benzy Paul has made the conception and design of the study and has been involved in drafting the manuscript. Dr. Ali Zameel, Dr. Durgesh Kumar and Dr. Sujesh PK have done the acquisition of data, analysis and interpretation of data. Dr Benzy Paul and Dr KA Aisabi have given the final approval of the version to be published.

Funding: Nil; Conflict of Interest: None initiated Permission from IRB: Yes

\section{References}

1. Abbud-Filho M, Ramalho H, Pires HS, Silveira JA. Attitudes and awareness regarding organ donation in the western region of Sao Paulo, Brazil. Transplant Proc. 1995;27(2):1835.

2. Chakradhar K, Doshi D, Srikanth RB, Kulkarni S, PadmaRM, Sruthi RS. Knowledge, Attitude and Practice Regarding Organ Donation among Indian Dental Students. Int J Org Transplant Med. 2016;7(1): 28-35.

3. Ghods AJ. Ethical issues and living unrelated donor kidney transplantation. Iran J Kidney Dis. 2009; 3(4): 183-191.

4. Annadurai K, Mani K, Ramasamy J. A study of knowledge, attitude and practices about organ donation among college students in Chennai, Tamil Nadu. Prog Health Sci 2013; 3(2):59-65.

5. Government of India. Transplantation of Human Organs Act, 1994. Available at: http://www. mohfw. nic.in/

Pathology Update: Tropical Journal of Pathology \& Microbiology Available online at: www.medresearch.in 781 | P a g e 


\section{Original Research Article}

6. Lima CX, Lima MV, Cerqueira RG, Cerqueira TG, Ramos TS, Nascimento M, Andrade CR, Cunha DG, Garcia SL. Organ donation: Cross sectional survey of knowledge and personal views of Brazilian medical students and physicians. Transplant Proc. 2010;42(5): 1466-1471. doi: 10.1016/j.transproceed.2009.11.055.

7. Akgun HS, Bilgin N, Tokalak I, Kut A, Haberal M. Organ donation: A cross-sectional survey of the knowledge and personal views of Turkish health care professionals. Transplant Proc. 2003;35(4):1273-1275. doi: 10.1016/S0041-1345(03)00437-8.

8. Bilgel H, Sadikoglu G, Bilgel N. Knowledge and Attitudes about Organ Donation Among Medical Students. Tx Med. 2006;(18):91-96.

9. Ganta SR, Pamarthi K, Lakshmi P KK. Knowledge and attitude regarding organ donation and transplantation among undergraduate medical students in North coastal Andhra Pradesh. Int. J Community Med Public Health. 2018;5(3):1064-1068. doi http://dx. doi. org/ 10.18203/2394-6040.ijcmph20180762.

10. Manojan KK, Raja RA, Nelson V, Beevi N, Jose R. Knowledge and Attitude towards Organ donation in Rural Kerala. Acad Med J India. 2014;2(1):25-27.

11. Mithra P, Ravindra P, Unnikrishnan B, Rekha T, Kanchan T, Kumar $\mathrm{N}$ et al. Perceptions and attitudes towards organ donation among people seeking healthcare in tertiary care centers of coastal South India. Indian J Palliat. Care. 2013;19(2): 83-87. doi:10. 4103 / 0973-1075.116701.

12. Tamuli RP, Sarmah S, Saikia B. Organ donation "attitude and awareness among undergraduates and postgraduates of North-East India". J Family Med Prim Care2019;8(1):130-136.doi:0.4103/jfmpc.jfmpc-206-18

13. Bhagya LM, Hemalatha S. Assessment of Knowledge on Organ Donation Among Degree College Students at Selected College, Tiruati", Int J Sci Res Sci, Eng Technol (IJSRSET).2019;6(5):21-28. doi: https:// doi. org/10.32628/IJSRSET19656.

14. Kumar VMB. A Study to Assess the Knowledge of Undergraduate Students Regarding Organ Donation in Selected Colleges at Abu Road with view to Develop a Pamphlet. IJRSI. 2016;4(1):442-446.

15. Deepthi K, Sunith S, Devi MB. Perceptions of medical students in a government medical college towards organ donation. J Evid. Based Med Health.
2015; 2(44): 7998-8005. doi: 10. 18410/ jebmh/2015/ 1075.

16. Sucharitha ST, Siriki R, Dugyala RR, Mullai, Priyadarshini, Kaavya, Roshini. Organ Donation: Awareness, attitudes and beliefs among undergraduate medical students in South India. Natl. J Res. Community Med 2013; 2(2): 83-88.

17. Saub EJ, Shapiro J, Radecki S. Do patients want to talk to their physicians about organ donation? Attitudes and knowledge about organ donation: a study of Orange County, California residents. J Community Health. 1998; 23 (6): 407-417. doi: https://doi.org/10.1023/A: 1018754023705.

18. Bharambe VK, Rathod H., Paranjape VM, Kanaskar N., Shevade S., Survase K, et al. Awareness regarding body and organ donation amongst the population of an urban city in India. NUJHS. 2015;5(4):51-57.

19. Saleem T, Ishaque S, Habib N, Hussain SS, Jawed A, Khan AA, Ahmad MI, Iftikhar MO, Mughal HP, Jehan I. Knowledge, attitudes and practices survey on organ donation among a selected adult population of Pakistan. BMC Med. Ethics. 2009;10:5. doi: 10.1186/ 1472-6939-10-5.

20. Soubhanneyaz A, Kaki A, Noorelahi M. Survey of public attitude, awareness and beliefs of organ donation in Western region of Saudi Arabia. Am J Internal Med. 2015;3(6):264-271. doi: 10.11648/j.ajim.20150306.18.

21. Ramadurga UY, Gupta A. Impact of an Educational Intervention on Increasing the Knowledge and Changing the Attitude and Beliefs towards Organ Donation among Medical Students. J Clin Diagn. Res. 2014;8(5):JC05-JC07. doi: 10.7860/JCDR/2014/6594. 4347.

22. Schauenburg H, Hildebrandt A. Public knowledge and attitudes on organ donation do not differ in Germany and Spain. Transplant Proc. 2006;38(5):12181220. doi: 10.1016/j.transproceed.2006.02.105.

23. Odusanya OO, Ladipo CO. Organ donation: Knowledge, attitudes, and practice in Lagos, Nigeria. Artif Organs 2006;30(8):626-629. doi : 10.1111/j.15251594.2006. 00272.x.

24. Sahu SK, Rath B, Rath S, Panigrahi S. Knowledge and attitude of educated people towards organ and body donation: A cross-sectional study in Southern Odisha. Sch J Appl Med Sci. 2017;5:2456-2462.

Pathology Update: Tropical Journal of Pathology \& Microbiology Available online at: www.medresearch.in 782 | P a g e 


\section{Original Research Article}

25. Hamed H, Awad ME, Youssef KN, Fouda B, Nakeeb AE, Wahab MA. Knowledge and attitudes about organ donation among medical students in Egypt: A questionnaire. J Transplant Technol. Res 2016;6 (1): 155. http://dx.doi.org/10.4172/2161-0991.1000155.

26. Bathija GV, Ananthesh BG, Bant DD. Study to Assess Knowledge and Attitude towards Organ Donation among Interns and Postgraduates of a Medical College in Karnataka, India. Natl.J Community Med. 2017; 8(5):236-240.

27. Coelho JC, Cilião C, Parolin MB, de Freitas AC, Gama Filho OP, Saad DT, et al. Opinion and knowledge of the population of a Brazilian city about organ donation and transplantation. Rev. Assoc Med Bras (1992) 2007; 53:421-425. doi: http://dx.doi.org/10. 1590 /S0104-42302007000500018.

28. Sander SL, Miller BK. Public knowledge and attitudes regarding organ and tissue donation: An analysis of the Northwest Ohio community. Patient Educ Couns. 2005; 58 (2): 154-163.doi:10.1016/j.pec. 2004. 08.003.

29. Bapat U, Kedlaya P, Gokulnath. Organ Donation, Awareness, Attitudes and Beliefs among Post Graduate
Medical Students. Saudi J Kidney Dis Transpl. 2010; 21 (1) :174-180.

30. Dutra MM, Bonfim TA, Pereira IS, Figueiredo IC, Dutra AM, Lopes AA. Knowledge About Transplantation and Attitudes Toward Organ Donation: A Survey Among Medical Students in Northeast Brazil. Transplant Proc. 2004; 36(4): 818-820. doi: 10.1016/j. transproceed. 2004.03.066

31. Burra P, De Bona M, Canova D, D'Aloiso MC, Germani G, Rumiati R, Ermani M, Ancona E. Changing attitude to organ donation and transplantation in university students during the years of Medical School in Italy. Transplant Proc. 2005;37(2):547-550. doi: 10. 1016/j.transproceed.2004.12.255

32. Zublee Foundation. ORGANOTHON"-The Run to see Others Smile; 2017. Available from: http:/www. zubleefoundation.com/event/organothon-run-see-others - smile-2017/.

33.Guwahati R. Ministry of Health and Family Welfare, Govt.of India. Walkathon Organized by ROTTO Guwahati; 2018. Available from: http://www. rottoguwahati. org/ hospital-charts/.

\section{How to cite this article?}

Paul B, Zameel A, Aisabi K.A, Kumar D, Sujesh P.K. Knowledge and attitude towards organ donation among people seeking health care in Kozhikode, Kerala, India. Trop J Path Micro 2019;5(10):777-783.doi:10.17511/jopm.2019. i10.05. 